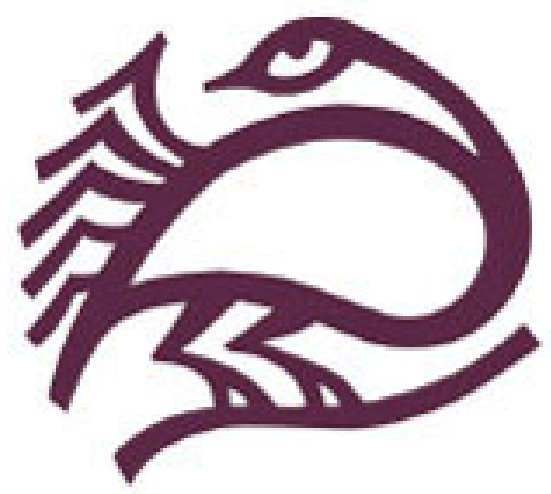

The Tantura Case in Israel: The Katz Research and Trial Author(s): Ilan Pappé

Source: Journal of Palestine Studies, Vol. 30, No. 3 (Spring 2001), pp. 19-39

Published by: University of California Press on behalf of the Institute for Palestine Studies

Stable URL: http://www.jstor.org/stable/10.1525/jps.2001.30.3.19

Accessed: 28/03/2014 10:31

Your use of the JSTOR archive indicates your acceptance of the Terms \& Conditions of Use, available at http://www.jstor.org/page/info/about/policies/terms.jsp

JSTOR is a not-for-profit service that helps scholars, researchers, and students discover, use, and build upon a wide range of content in a trusted digital archive. We use information technology and tools to increase productivity and facilitate new forms of scholarship. For more information about JSTOR, please contact support@jstor.org. 


\title{
The Tantura Case in Israel: The Katz Research aND Trial
}

\author{
ILAN PAPpé
}

This article examines the academic and legal controversy that has arisen in Israel over a graduate thesis using oral history the taped testimonies of both Arab and Jewish witnesses to document a massacre carried out by Israeli forces against the Palestinian coastal village of Tantura in late May 1948. Though the researcher, Teddy Katz, is himself a Zionist, the case sheds light on the extent to which mainstream Zionism is prepared to go in discouraging research that brings to the fore such aspects of the 1948 war as "ethnic cleansing." The article also discusses the research itself and summarizes the actual massacre as it can be reconstructed from the available sources. It is followed by excerpts from some of the transcripts.

ON 21 JANUARY 2000, the Israeli daily Ma'ariv published a long article on the massacre of Tantura. Written by journalist Amir Gilat, the article was based mainly on a master's thesis by Teddy Katz, a student in the department of Middle Eastern History at Haifa University. The thesis, entitled "The Exodus of the Arabs from Villages at the Foot of Southern Mount Carmel," had been awarded the highest possible grade for a master's thesis several months earlier. (It had been submitted in March 1998, but for complications having nothing to do with the case itself, was examined only at the end of 1999.) ${ }^{1}$ The thesis is microhistorical research on the 1948 war focusing on five Palestinian coastal villages between Hadera and Haifa, particularly on the villages of Umm Zaynat and Tantura. The testimonies reproduced by Katz in his fourth chapter tell a chilling tale of brutal massacre, the gist of which is that on 22-23 May 1948, some 200 unarmed Tantura villagers, mostly young men, were shot dead after the village had surrendered following the onslaught of Haganah troops.

\section{Katz's Research and the Role of Oral History}

The basic idea behind Katz's thesis is that even works focused exclusively on the 1948 war, such as Benny Morris's Birth of the Palestinian Refugee Problem, 1947-1949, ${ }^{2}$ have not dealt in detail with the fate of individual villages. At the heart of the thesis are the oral testimonies Katz obtained, for

\footnotetext{
ILAN PAPpé is a professor in the department of political science at Haifa University and the author of a number of books, including The Making of the Arab-Israeli Conflict, 1947-1951 (London: I. B. Tauris, 1992).
} 
microresearch of this kind could not have been carried out relying solely on archival material, which for individual villages is exceedingly scant.

Certainly, Katz was aware of the pitfalls of oral history, but his supervisor guided him, rightly in my opinion, to treat oral history as a significant and vital component in the historical reconstruction of the Nakba (the Palestinian Catastrophe of 1948). Especially with the advent of electronic recording, oral history has gained increasing recognition in the past decades in the academic community worldwide: there are more than a thousand oral history programs under university auspices in the United States alone. ${ }^{3}$ Nor is written documentation still seen as necessarily more authentic or reliable than oral history. This is particularly true with regard to Israel Defense Forces (IDF) documents concerning the 1948 war, which are mainly reports or correspondence by military men whose aim is at times less to report than to conceal. This means that historians must often use as much guesswork and imagination in reconstructing what happened from the documents as they would in working with oral testimonies. (If one thinks ahead fifty years and imagines the contrast between official IDF reports concerning the latest intifada and the ocular testimony of witnesses, one has some idea of the problem.)

Oral history is not a substitute for written evidence, but it is particularly important in validating and filling in the gaps in the documentary evidence, which gives us the "bare bones." Thus, what is in the official Israeli record (the History of the Haganab, ${ }^{4}$ for example) a brief reference to the act of occupying a village-or "cleansing" it, to use the actual term of the Jewish texts ${ }^{5}$ - becomes in Palestinian history a detailed account of assault, expulsion, and in some cases massacre. Indeed, in the case of Tantura, the massacre might not have come to light at all had it not been for oral testimony on the Palestinian side-later corroborated by Jewish testimony-because the piecemeal evidence currently available in the Israeli archives is too fragmentary (as we shall see) to more than hint at what happened. ${ }^{6}$ In this case, then, it is the documents that fill out the oral history, rather than the reverse.

Recently, the Israeli historian Omer Bartov wrote very movingly about the value of oral history. He was writing about its use in the reconstruction of the Holocaust, and though no comparison between the Holocaust and the Nakba is intended, one of his passages serves to remind us of the value of oral history as a legitimate tool in reconstructing past traumas:

The memory of trauma is often murky, unstable, contradictory, untrustworthy. ... What we learn from [memoirs of camp survivors in this case] are not the fine details of camp administration, train schedules, ideological purpose and genocidal organization. These are matters far better left for historians. What we learn is the infinity of pain and suffering that makes the memory of those years into a burden whose weight stretches far beyond the ephemeral human exis- 
tence, a presence that clings to the mind and inhabits the deep recesses of consciousness long after it should have been cleansed and washed away. ${ }^{7}$

In writing his thesis, Katz was well aware of the "murkiness" of the picture derived from the memories of participants and survivors so long after traumatic events. But he was not interested in fine details; he wished to learn the overall picture, leaving behind, perhaps forever, certainties about exact chronology and names and precise numbers. He wished to learn the pain and suffering as it was experienced by people in the midst of war and to show the kaleidoscope of perspectives from the various testimonies. Into these he wove the published and unpublished sources at his disposal-yet another perspective. And despite the inevitable discrepancies in the details, the broad picture he found is remarkably consistent. It is important to mention that he uses the same research technique for Umm Zaynat, with witnesses, Palestinian and Jewish, each from their own vantage point, telling how they saw the village's occupation and the expulsion. Yet in the case of Umm Zaynat, there is no mention of massacre.

Katz was able to overcome the suspicion and, indeed, delegitimization that is usually applied in Israel to Palestinian oral history (and, indeed, to Palestinian history in general) only because he succeeded in ob-

Katz was able to overcome the delegitimization applied to Palestinian oral bistory only because be also obtained testimonies from Jewish soldiers who bad participated in the events. taining testimonies about the massacre not only from Palestinian witnesses but also from Jewish soldiers who had participated in the events. Had there not been corroborating Jewish testimonies on the Tantura affair, even the article in Ma'ariv would not have been taken so seriously.

Katz interviewed 135 persons for his thesis. The Tantura chapter is based on the testimonies of forty witnesses, by coincidence twenty Arabs and twenty Jews, all of them taped. Tracking down the Palestinian survivors was more difficult than finding the Jewish soldiers: Tantura had been captured by the 33rd Battalion of the Alexandroni Brigade, and the names of the veterans were readily obtainable. The Palestinians he interviewed, on the other hand, most of whom live in Furaydis and Jisr al-Zarqa, villages near Tantura, as well as Tulkarm in the West Bank, had to be found by word of mouth through Jews who knew them or through the intervention of Palestinians from Tantura living abroad. Moreover, while Jewish soldiers are accustomed to being sought out to talk about their war experiences, the Tantura survivors still living in Israel were reluctant to participate in a project in which they were asked to shed light on Jewish barbarism during the war.

The thesis is not without its faults. When he wrote it, Katz was not aware of some important material (which in fact add confirmation to the story, of which more later), and he failed to address the important issue of why, in contrast to many other massacres of the 1948 war, knowledge of this one 
had apparently not gone beyond the immediate circles of the survivors: neither Walid Khalidi's seminal work All That Remains ${ }^{8}$ nor the exhaustive Palestinian Encyclopedia, ${ }^{9}$ for example, mentions it. Other relatively minor methodological deficiencies, typical in theses of this level and kind, later became the basis for the prosecution's case in the libel suit brought against Katz, which will be described below. Nonetheless, Katz's thesis is a solid and convincing piece of work whose essential validity is in no way marred by its shortcomings.

Much of the subtlety of the academic work was lost in the bald summary of the Ma'ariv article, which made no mention of the methodological complexities involved. Still, the gist of the story was accurately conveyed. The article also includes positive and negative evaluations by a number of scholars. Among those praising the work were Professor Asa Kasher, a philosopher from Tel Aviv University and the author of the IDF's ethical code; Meir Pail, a military historian of the 1948 war; and this writer. These scholars were more categorical than Katz in characterizing the Tantura events. Thus, while Katz had not used the word "massacre" either in his thesis or in interviews about his work, they did not shrink from the term, and Professor Kasher called what happened in Tantura a "war crime." Three historians with negative assessments were also cited in the article. Only one of the three, Yoav Gelber, had actually read the thesis, but the others did not hesitate to join him in condemning it as, at best, the product of unfounded rumors or, at worst, a work written with the intention of weakening Israel's image and position in the peace negotiations.

Gilat also succeeded in tracking down some of the witnesses Katz had interviewed. The Palestinians repeated what they had said to Katz, but some of the Jews recanted. Several of them even joined the lawsuit against him, submitting affidavits denying their testimony-despite the fact that their testimonies are on tape and very clear. One of those who recanted, Shlomo Ambar, affirmed in his affidavit that he did not recall anything he said to Katz.

\section{What Happened in Tantura?}

Since the thesis was written, several other pieces of evidence have come to light that reinforce Katz's findings. Four documents were extracted from the IDF archives. One was a report mentioning twenty Palestinians killed in the battle, ${ }^{10}$ followed by a report a week later from IDF headquarters complaining that the unburied corpses in the village could lead to the spread of epidemics and typhoid. ${ }^{11}$ In the third document, the Israeli general chief of staff inquired about reports that had reached him "about irregularities in Tantura" and received the response that "overenthusiasm because of the victory" had led to some damage inflicted "immediately after our people entered the place." ${ }^{2}$ Finally, a document from the Alexandroni Brigade to IDF headquarters in June notes: "We have tended to the mass grave, and everything is in order." 13 
Another piece of evidence Katz had not been aware of was a passage in a 1951 Palestinian memoir that includes a graphic description of the massacre. It is brought by Marwan Iqab al-Yihya, a survivor who had reached Haifa after the massacre and described to the author what he had seen with his own eyes. ${ }^{14}$ Additional testimonies were recently collected from Tantura survivors living in refugee camps in Syria by a Palestinian researcher, Mustafa al-Wali, and published in the Palestinian journal Majallat al-Dirasat alFilastiniyya. ${ }^{15}$ Some of these testimonies are reproduced in the current issue of this journal.

The Jewish and Palestinian testimonies, in combination with the few written sources we have, including the official history of the Alexandroni Brigade, ${ }^{16}$ give us a clear overall picture of what happened in Tantura on 22-23 May 1948, though many details are still obscure and probably will remain so. On the eve of the occupation, Tantura was a large village with a harbor-fit for boats, not ships—on the coast thirty-five kilometers south of Haifa and a few kilometers west of the main road linking Haifa to Jaffa and Tel Aviv. From the evidence, it transpires that after the battle ended and the village had surrendered to the Alexandroni Battalion, some 200 more people were killed. The IDF documentation, as noted above, refers to about twenty Arabs killed during the battle itself, and the commander in charge of the operation affirmed in his interview with Katz that no more than thirty Palestinians had been killed in the fighting. Yet one of the Jewish witnesses Katz interviewed, who personally supervised burials, testifies having counted 230 Palestinian corpses himself.

According to the witnesses, the killings took place in two stages. The first phase was a rampage. From Katz's interviews with the soldiers, it was unleashed by the soldiers' anger caused by shots fired at them after the village had officially surrendered. It appears that one or two snipers were still active and that they killed or wounded one, two, or even eight Jewish soldiers (the testimonies differ on the numbers) following the surrender. One of the Jewish eyewitnesses said that a particularly popular soldier had been killed in that fire. The rampage phase left about 100 people dead.

The second phase was more premeditated. It was carried out by intelligence units and people belonging to logistical units, most of whom lived in the nearby Jewish settlements of Atlit, Binyamina, Maayan Zvi, and Zichron Yaacov. These units systematically executed men suspected-often unjustifiably, it seems — of concealing personal weapons in their homes or of belonging to the Arab volunteers who had come to assist the Palestinians. These executions were finally stopped by people from Zichron Yaacov, who accused the soldiers of killing the wrong people. Another 100 or so victims, according to the witnesses, were dispatched in this phase.

After the rampage, the people of Tantura had been rounded up and led to the beach, where the men were separated from the women and children (up to twelve or thirteen years old). Aided by lists of names, the intelligence and logistics soldiers selected groups of seven to ten or even more and took 
them back to the village, either to the graveyard or a place near the mosque. They were either seated or made to stand against a wall and were shot at the back of the head.

Those executed were between the ages of thirteen and thirty. Those within that age range who were spared were held in detention camps for a year and a half, separated from the women and children and old people who had been transported after the massacre to the nearby village of Furaydis. This village, by the way, along with Jisr al-Zarqa, were the only two out of sixty-four villages on the road between Haifa and Tel Aviv that were not wiped out by the Jewish forces. This was because men from these villages had traditionally worked in the nearby Jewish settlements, which pressed to have them spared so they could continue to benefit from the cheap labor. Most of the men of Tantura were expelled to the West Bank after their detention, where they were joined by their families. Most of those who remained in Israel were able to do so through the intervention of Jews who knew them.

In general, the ethnic cleansing in Palestine as a whole and in the area between Hadera and Haifa in particular was carried out against a background of vague instructions from above, as is testified by the commander of the battalion occupying Tantura. According to these instructions, every commander occupying a village had full authority to do with the inhabitants as he saw fit, whether they surrendered or were taken prisoner.

The usual practice followed by Alexandroni in occupying a village-the brigade also captured the villages of Hayriyya, Kafar Saba, Qaysariya, Sakiyya, Umm Zaynat, and (later) 'Ayn Ghazal, Ijzim, and Jaba', among others-was to expel the inhabitants while the battle was in progress. Villages were purposely not fully encircled, and one of the flanks would be left open so that the inhabitants could be put to flight through this "open gate." But in Tantura, due to lack of coordination during the battle, the village was completely surrounded; with Jewish boats offshore blocking the sea route and the Alexandroni units on land, there was no "escape gate." The concentration of so large a village in the hands of the occupier-Tantura had about 1,500 inhabitants-produced the rampage, the massacre, and the executions. From the testimony of the perpetrators, it would appear that some saw the executions as being in the service of the Zionist security apparatus (killing young men they saw as soldiers of the enemy), others as part of a personal vendetta. The pattern must have been similar in the almost forty other places where massacres occurred.

Getting testimonies from both sides was sometimes painful. Those who actually witnessed the acts of killing during the execution phase, aside from the perpetrators, were generally young children or people who either worked with Jewish intelligence or were about to be killed and were saved at the last minute by Jews from nearby settlements. An air of uneasiness accompanies many of the testimonies. Mustafa Masri, who as a young child had witnessed the killing of his entire family before his very eyes, concludes a 
particularly chilling interview with Katz by uttering "But believe me, one should not mention these things. I do not want them to take revenge against us. You are going to cause us trouble. I made a mistake in giving you the name of the person [a local Jew] who handed my family over." I think it is even clearer why the Jews did not talk about the massacre. As one of the Jewish witnesses, Joel Solnik, said to Katz "There were shameful things there, very shameful. It was one of the most shameful battles fought by the IDF. . . they did not leave anyone alive."

The resistance to talking about what happened came out clearly in an interview with a veteran Israeli general, Shlomo Ambar, who had been a young officer in the battle. He tells Katz that he had never gone back to Tantura and that he had seen things he does not want to talk about. Pressed by Katz, he says, "I associate [what had happened in Tantura] only with this. I went to fight against the Germans who were our worst enemy. But when we fought we obeyed the laws of the war dictated to us by international norms. They [the Germans] did not kill prisoners of war. They killed Slavs, but not British POWs, not even Jewish POWs-all those from the British army who were in German captivity survived." Katz prods him further: "Come on, we are fifty years later, you'll go to heaven and they'll say that you had a chance to talk and didn't." Ambar: "I had sinned so much in my life. . . . On this I would be questioned in heaven?" Ambar looks at Katz's tape recorder: "Why are you using that?" Katz: "Because I can't remember everything." Ambar: "If I don't want to tell, it means I'm hiding something. It means that the occupation [of Tantura] was not one of our most successful battles." Katz: "You talk about Tantura, and you mention what even the Germans did not do." Ambar: "That's right. They did not kill Western prisoners, only Russians." A few minutes later, he adds, "Let me tell you, I do not recall too well. The intention was to empty the village, and people died in the process.... People naturally are attached to their home place and do not want to go, so under the pressure of an occupying army, they were made to leave, toward the east. Period. Ask me something else."

\section{The Legal and Academic Battle}

A few days after the affair was publicized by Ma'ariv, the veterans of the Alexandroni Brigade sued Katz for libel, asking for more than one million shekels in damages. One would have assumed that Haifa University would stand behind Katz. Given the high grade he had received, any discredit of his work-especially in so public a way-could only reflect poorly on the university's standards, but the moment the legal process began, the university began acting as if he were already guilty of incompetence at best or fraud at worst. Spearheading the crusade against Katz within the university were senior members of the Department of Erez Israel Studies, which has always been in the forefront of providing scholarly scaffolding for the Zionist narrative. As a result of the campaign, the university refused to offer Katz any 
legal, moral, or practical support in facing the suit. It was a Palestinian legal NGO in Israel, Adalah, that provided assistance on a pro bono basis. Katz was in disgrace. His name was summarily removed from a list of those to be honored for their work at a special ceremony. (Since the list had already been printed, his name had to be erased with tippex.) His status at the university was equivalent to that of an employee suspended, and his hopes of pursuing an academic career were shattered, at least for the time being.

Before the trial began, Katz tried to persuade the court not to take the case, arguing that it was a scholarly debate that should be determined not in court but within the university. If the university had supported this effort, he may have succeeded in avoiding a trial, but the university refused, and the trial opened as planned.

The trial began on 13 December 2000, with Katz being called to the witness box by the prosecuting attorney. The crux of the prosecution's case rested on six references-out of 230 - in which Katz either misquoted or interpreted too freely what the witnesses said. In Ambar's testimony, Katz substituted the word "Germans" for "Nazis." In another, he summarized the testimony of a Tantura survivor, Abu Fihmi, as describing a killing, where the witness did not say this directly (though in fact, this is clearly what he meant). In four other instances, Katz wrote something that does not appear in the tapes but only in his written summaries of the conversations. No discrepancies were found in any of the remaining 224 references concerning Tantura.

The presentation of these discrepancies consumed the first two days of the trial. When the court broke for the day at the end of the second day, a member of Katz's team of three lawyers (which had also checked through every reference against the tapes) exulted in a private conversation that the prosecution had exhausted its entire case. ${ }^{17}$ The cross-examination by the defense concerning this material, and the defense's case, was to begin the following day. None of the Jewish soldiers had agreed to appear in court, but since it was expected to be a long trial it was expected that they would be forced to testify. The defense and some of Katz's supporters were looking forward to a trial that would mark the first time in Israel's history that, in effect, Israel's role in the Nakba was on trial.

That night, however, for reasons Katz himself cannot explain even today, he signed an agreement that in essence repudiated his own academic research. Weakened by a stroke several weeks earlier and subjected to enormous pressures by his family, friends, and neighbors in the kibbutz where he lived, he acquiesced on the advice of one of his lawyers (a cousin of his) to bring an end to the whole affair; he was likewise assured by the university lawyer, an unofficial member of his legal team, that signing the agreement would be for his own good, appearing to hint that it would enable him to continue his studies at Haifa University.

The agreement Katz signed took his other two lawyers totally by surprise. Titled "An Apology," the agreement is so sweeping as to bear an uncomfort- 
able resemblance to a police "confession" extracted under dubious conditions. The section relating to his research reads as follows:

I wish to clarify that, after checking and re-checking the evidence, it is clear to me now, beyond any doubt, that there is no basis whatsoever for the allegation that the Alexandroni Brigade, or any other fighting unit of the Jewish forces, committed killings of people in Tantura after the village surrendered. Furthermore, I wish to say that the things I have written must have been misunderstood [by the press] as I had never intended to tell a tale of a massacre in Tantura.... I accept as truth [only] the testimonies of those among the Alexandroni people who denied categorically the massacre, and I disassociate myself from any conclusion which can be derived from my thesis that could point to the occurrence of a massacre or the killing of defenseless or unarmed people.

Twelve hours later, Katz formally regretted his retraction and wanted to continue the trial, but the judge refused. The judge's ruling made no reference to the merits of the case, but only to the court's ability to accept Katz's retraction of his retraction. As this report is written, the matter now rests with the High Court, which will decide by April 2001 whether the trial can resume.

The Israeli press, which had given front-page coverage to Katz's retraction, barely mentioned his efforts to rescind it. He was depicted in the three major newspapers-both in the news sections and, later, in op-eds-as a fabricator, a pseudohistorian who had invented a nonevent for ideological reasons (a ridiculous allegation given that Katz, like the lawyer for the prosecution, is a member of Meretz). Because Katz had given in so early on, after two days of testimony wholly taken up with undeniable discrepancies, it was assumed that the six discrepancies were representative of the entire work. From there it was all too easy to conclude that there had been no massacre and probably not really a Nakba in 1948 . The national radio and television exulted in Katz's "exposure." Even left-wing journalists like Tom Segev remarked that there may have been a massacre, but it met the wrong historian. ${ }^{18}$

Haifa University did not accept his retraction of his denial either and acted as if the agreement with the prosecution were valid. On 26 December 2000, the prosecutor urged the university to strip Katz of his title. The university set up two committees, one to check the tapes against the quotations in the thesis, the other to investigate whether there had been failures of the supervision process. The fact that Katz's academic adviser was a Druze and that one of his examiners was rumored to be a Palestinian (in Israel the examination process is anonymous) was the subtext that nobody openly talked 
about. Nonetheless, these additional factors undoubtedly made it easier for the university to move ahead with the unprecedented procedure of stripping Katz of his title. His own department, the Department of Middle Eastern History, stopped it just in time, demanding that some of the measures be frozen until the court issues a verdict.

As a faculty member of Haifa University, I posted on the university's internal Web site some of the more important transcripts of the more than sixty hours of Katz's tapes, most of which had not been

After reading the transcripts, a number of people, even if they had reservations about the quality of Katz's research, no longer bad any doubts about what happened in Tantura. referred to in court. They include horrific descriptions of execution, of the killing of fathers in front of children, of rape and torture. They come from both the Jewish and the Palestinian witnesses. As a result of these transcripts, a number of people, even if they had reservations about the quality of Katz's research, no longer had any doubts about what happened in Tantura, which is after all the important issue. I also published an open letter accusing the university of moral cowardice. A lecture of mine at the School of History, scheduled long before, was abruptly canceled without explanation. Only two of my colleagues, in a university with hundreds of faculty members, openly protested this basic violation of free speech. But then again, this was in January 2001, the same month that Israel's famed technical university, Technion, took a decision giving its president the authority to expel students and lecturers involved in political activity on campus.

Without doubt, the response to the Tantura case reflects the hardening of attitudes in Israel that has followed the outbreak of the al-Aqsa intifada and especially the October events involving the Palestinian citizens of Israel. Since then, the moral voice of Jews in Israel has been all but silenced. "Prophets of Peace" such as David Grossman, Amos Oz, and A. B. Yehoshua, have publicly stated in various radio interviews that they were wrong to trust the Palestinians ${ }^{19}$ and, far more important, signed a petition published on the front page of Ha'Aretz on 2 January 2001 emphasizing their unequivocal opposition to the Palestinian right of return. It is probable that had the Katz case begun before the outbreak of the present intifada, or even better during the more optimistic days of the Oslo process, the public and academic reaction would have been somewhat more moderate. Poor Katz, himself a Zionist, could not have chosen a worse time to bring evidence of a massacre, raising the spectre of Israeli responsibility in crimes of war in 1948.

All is not bleak, however. Before the trial opened, an association organized to help Katz convened an impressive conference in November 2000 in Tel Aviv, where for the first time old-timers in the Israeli peace camp, including Shulamit Aloni and Uri Avineri, talked openly about the 1948 ethnic cleansing. The event included screening of the film 1948 by Muhammad Bakri, itself an impressive piece of oral history in which Jews and Palestinians testify about the ethnic cleansing in 1948. Indeed, this was one of the first 
public gatherings where the term "ethnic cleansing" was freely used and where the central question was not whether collective crimes had been committed in 1948, but rather their current implications with regard to a peaceful settlement of the Palestine conflict. Many speakers wondered how research in Israel on the Nakba could be furthered and protected.

More recently, on 2 February 2001, a group of highly respected academics from Tel Aviv University and the Hebrew University organized a day of study on the relationship between the legal system and academia. Among the participants, surprisingly, were the presiding judge in the Katz affair and the rector of Haifa University. The general tenor of the meeting seemed to be against any interference by the legal system in academic research; more concretely, many participants criticized Haifa University for its conduct in the Katz affair. Professor Asa Kasher and Meir Pail reiterated their support for Katz's research, specifically stating that the inaccuracies uncovered by the prosecution did not significantly undermine the quality of the dissertation.

\section{Some Implications}

Thus far, the Katz affair sheds light on and raises issues in three areas: the place of Palestinian oral history in the historiography of 1948 and the relationship of the Israeli judiciary and academia to the Nakba. Concerning the first, one of the most notew orthy elements of the debate over the Katz affair was the way in which Palestinian oral testimony was treated. Traditionally, Palestinian oral history - and indeed written works in general by Palestinians concerning 1948 - have been branded in Israel as sheer propaganda and wild flights of "Oriental" imagination. Yet the legal challenges to Katz's thesis centered not on the truthfulness of the Palestinian testimonies per se or on the validity of oral history as a tool in research, but on Katz's mishandling of the testimony. Furthermore, several historians in dismissing Katz's findings used as evidence to support their case the fact that the massacre is not mentioned in Walid Khalidi's All That Remains ${ }^{20}$-a work not treated in Israel as an authority before. This is not to say that a "revolution" in Israeli attitudes toward Palestinian history has occurred, and it is obvious that the Palestinian sources were considered reliable only insofar as they did not mention the massacre. Still, if the trial resumes, the oral testimonies by Palestinians on the Nakba-like the testimonies of Jews on the Holocaust in the Eichmann and Demanjuk trials-will have to be treated as a legitimate source, both in court and in scholarly debate.

The second issue raised by the case is the attitude in principle of the judicial system on the question of the Nakba. Zionist historiography on 1948 has been almost universally accepted in Israel; even the "new historians" have refused to use the term "ethnic cleansing" in reference to 1948 and with few exceptions have been unwilling to concede that there was a "master plan" of expulsion or conquest. ${ }^{21}$ It is thus that the concept of war crimes in relation to the 1948 war has never been raised. Yet it is difficult to see in any other 
terms the expulsion (direct and indirect) of some 750,000 Palestinians, the systematic destruction of more than 400 villages and scores of urban neighborhoods, as well as the perpetration of some forty massacres of unarmed Palestinians. Criminal suits are unlikely to be brought by Palestinians, which legally speaking would face the principle of obsolescence (only grandchildren who can prove direct harm can sue, at least theoretically).

This is why the Tantura case is so important. It is the only case so far in the history of Israel in which the Nakba has been discussed in court. By not allowing the trial to continue, the judge prevented Palestinian survivors from telling their story in court. It also indirectly preempted future research on 1948 that does not subscribe to Zionist ideology by giving future scholars reason to worry about the legal consequences of taking on the struggle over the past. This becomes a particularly sensitive field of research in that it deals with issues of the past that are relevant to the nature of a future comprehensive settlement of the Palestine question.

The third issue is Israeli academia's approach to the Nakba. A number of members of the academy were only too happy to swoop down like vultures on the methodological defects in the work of a historian just starting out on his academic career-easy prey by all accounts. One could speculate that the motivation was not simply denial of the massacre-in fact the Nakba-but a kind of recognition that if Katz had won the case, Israeli academia's role for more than fifty years in suppressing the truth about the Nakba would itself be on the dock. Jewish participants in the 1948 war were surprised when approached by a Jewish researcher who did not, as is usually the case in Israel, want to hear about their heroism in 1948 but rather confronted them with their barbarism. The more honest among them were not afraid to tell what they had seen, because they were confident, given the reigning ideology that is not opposed to killing Arabs, that even such acts would be protected as exceptional or legitimate. For some, the opportunity to confide in Katz helped to alleviate personal guilt and remorse. Zionist scholars of 1948, it would appear, are less in need of such alleviation and have lived comfortably enough with their role in covering these crimes. One can perhaps find extenuating circumstances in the actions of the perpetrators, but not for the deniers.

It is difficult to predict the final results of the Katz case, but based on reactions so far, one can assume that the Jewish academic establishment will continue to try to prevent the legitimization of oral history for 1948 and that it will be more vigilant in making sure that fresh historians confirm the broad lines of the Zionist narrative on 1948. Admittedly, certain foundational myths, such as the "few against many" and "Arab voluntary flight," have already been shattered, but the overall narrative has survived these setbacks. The argument now runs as follows: yes, some Palestinians were expelled during the war, but it was simply a byproduct of the fighting, certainly not because of any plan of mass expulsion. Hence, such expulsions as did take place 
were an integral part of any conventional war and have nothing to with ethnic cleansing and war crimes. ${ }^{22}$

The only way to confront this reality is to encourage independent NGOtype research institutions in Palestine and in Israel entrusted with the task of expanding research on the Nakba. The first priority is to establish a bank of oral testimonies, before there is no one left to interview.

It should be clear by now that no true reconciliation between Israelis and Palestinians can ever take place without full awareness of what happened in the Nakba. It is for this reason that research on the Nakba by Jewish scholars has to be part of a public campaign based on clear positions vis-à-vis the conflict and its solution. The questions of compensation, the Palestinian right of return, and Israeli moral responsibility are anyhow already in the public mind of both Israelis and Palestinians as negotiable issues. Finally, research on the Nakba requires some kind of international protection. The historical research, the public campaign, and the legal defense should be part and parcel of the same political action in Palestine, Israel, and abroad.

\section{Appendix: Excerpts from the Transcripts*}

\section{Dan Vitkon, a soldier in Alexandroni}

Vitkon: In Tantura, someone who later was a big shot in the Israeli Ministry of Defense was an officer in Tantura, and he killed with his own pistol, one Arab after the other, because they did not disclose where they hid their weapons.... He shot them one after the other in his Parabelum and he killed there [the name and identifying details are given].

\section{Yosef Graf, a guide from Yaacov Zichron who accompanied the units}

Graf: The Arabs raised the white flags, the kuffiyya, the hatta...

Katz: Wait a minute. There was no battle going on?

Graf: Before that, there were clashes, sure. Skirmishes. Our guys had taken cover and shot back at the Arabs who then raised the white flags. . . I called to our guys: "Don't advance!" They did not heed and were shot at, and then they [the soldiers] assaulted and killed them all.

Katz: That is, in response to the shooting at them, they stormed?

Graf: Yes. And killed almost everyone.

Katz: How many, roughly? You remember a figure-twenty, fifty?

Graf: No. I think they counted in the end 140 or 150, all young men.

Katz: Were these people killed in the battle?

Graf: While occupying the village, there were many dead who were shot while staying in their homes in the village.

Katz: After the surrender, actually?

\footnotetext{
* Translated from the Hebrew by Ilan Pappé.
} 
Graf: There was no surrender. It was occupation.

[Later in the conversation]

Graf: I am telling you these [Alexandroni] people, they massacred.

Katz: In an amok attack?

Graf: Yes.

\section{Salih 'Abd al-Rahman (Abu Mashayiff), from Tantura}

Katz: How were people killed in Tantura?

Abu Mashayiff: There was fighting between them. In the end, they caught them on the coast, in Tantura, and took them near a huge building and killed them like this.

Katz: Which building?

Abu Mashayiff: Houses near the coast. The sea was next to the village.

Katz: Killed them after they surrendered?

Abu Mashayiff: After they had caught them.

Katz: How many, roughly?

Abu Mashayiff: Eighty-five.

Katz: You were there and saw it with your own eyes?

Abu Mashayiff: Yes.

Katz: How did it go? Only eighty-five were standing there, or the whole village was standing there?

Abu Mashayiff: No. Eighty-five stood. You know how it works. They came to the villagers as a whole who were all seated on the beach, and on the spot they said to this one and that one: "Get up! You, you. ..."

Katz: According to what?

Abu Mashayiff: They had names.

[Later in the conversation]

Katz: Shimshon Mashvitz stopped killing after he was stopped by Rehavia Altshuler?

Abu Mashayiff: Yes. He agreed after he had killed eighty-five people.

Katz: He alone killed eighty-five people?

Abu Mashayiff: Yes.

Katz: What was he using?

Abu Mashayiff: A Sten. He killed them. They stood next to the wall, facing the wall, he came from the back and killed them all, shooting them in the head.

Katz: Every time he placed several of them next to the wall?

Abu Mashayiff: Yes.

Katz: Groups of eight, five-how many?

Abu Mashayiff: Every group twenty or thirty people.

[Later in the conversation]

Abu Mashayiff: Twice or three times he changed magazines.

Katz: That is, one bullet per person?

Abu Mashayiff: Yes.

[Later in the conversation] 
Katz: How far where you from there?

Abu Mashayiff: Let's say, thirty meters.

\section{Tuvia Lishansky, a senior intelligence officer}

Katz: How many soldiers did you encounter?

Lishansky: Units of five or six soldiers.

Katz: That roamed the streets and killed anyone they saw?

Lishansky: Yes, yes.

Katz: And this is why?

Lishansky: Because they lost eight soldiers in the battle, and during the fighting they decided to execute.

Katz: How many were executed?

Lishansky: Not too many.

[Later in the conversation]

Katz: What was your impression of what had happened in the streets and the houses-how many died there?

Lishansky: Quite a lot, but I cannot tell you. The soldiers, after losing comrades, were rampaging, dropping to the ground everything. They were crazy, leaving havoc and destruction behind them.

Katz: And this is all because of the eight [soldiers] dead?

Lishansky: Yes. Look, they were not used to losing so many dead on our side. In most of the battles they did not encounter much resistance and the Arabs would run or surrender.

[ Later in the conversation]

Katz: From your experience, you know of such things [executions] in other places?

Lishansky: Yes, of course.

Katz: That people came, took people according to lists, and killed them on the spot?

Lishansky: Absolutely. I remember, there or in Jisr al-Zarqa, that for instance we caught someone suspected of killing a Jewish guard, and he was brought to Zichron police, was convicted, and I do not remember exactly what happened to him, but he was wasted.

Katz: But here I am talking about many people, taken according to lists and killed on the spot. ...

Lishansky: Yes, yes. We knew about these things. For instance, there were two from Jisr al-Zarqa. ...

Katz: But here we are talking about larger numbers.

Lishansky: Yes, I am just giving an example from Jisr.

\section{Mordechai Sokoler, a guide from Zichron accompanying the units}

Katz: The battle was over. The women, children, and old men stayed in the place. For how long?

Sokoler: A day or two. After they were transferred. 
Katz: With all the bodies?

Sokoler: With the bodies for two days. Then I brought people from Furaydis and buried them.

Katz: It means that the family members stayed in the village. . .

Sokoler: Another day or two.

Katz: With all the bodies?

Sokoler: Yes, yes.

[Later in the conversation]

Katz: How many people of Tantura surrendered with their hands over their head?

Sokoler: Two hundred and thirty.

Katz: Two hundred and thirty-is that an accurate number? You counted them?

Sokoler: No, I evaluated them, but after they were killed, we counted them.

Katz: And how many were there?

Sokoler: The same number.

Katz: Two hundred and thirty?

Sokoler: Yes.

Katz: How many were killed in the battle?

Sokoler: They were all killed in the battle. The sniper hit one of the soldiers in the leg, shooting began. And then they were killed, all hell broke out. They did not know who was shooting.

Katz: For killing 230 people, it takes time.

Sokoler: [Laughing] They were concentrated in one spot.

[Later in the conversation]

Katz: So you have counted and reached 230?

Sokoler: Yes.

Katz: From this you say only a few, maybe ten were killed in the battlefield? Sokoler: Only ten [gives the names of the people of Tantura he knew who died in the battle].

\section{[Later in the conversation]}

Katz: The only question I still have is about where you personally were, so that I can know what you saw with your own eyes.

Sokoler: The worst things I didn't see. I had not seen the end of the battle. I left the place. All and all, I was there one day and a half, mainly busy with burying.

Katz: You were involved personally with the burial ...

Sokoler: I and Arabs from Furaydis laid [in the grave] one Arab after the other, closed their eyes with the hatta, row on top of row, and that was it. Katz: I understand that only their eyes and heads were covered [with the kuffiyyeh].

Sokoler: Only the heads, we buried them with their clothing and all ...

Katz: And this was two days after the fighting. 
Sokoler: After eight days, I came back to the place where we buried them, near the railway. There was a big mound, for the bodies had inflated. After two or three days, the mound had gone down.

Katz: Two or three days later?

Sokoler: Yes.

Katz: I understand that later they added soil and spread it over the graves. Sokoler: This I do not know.

\section{Ali 'Abd al-Rahman Dekansh (Abu Fihmi), from Tantura}

Abu Fibmi: They entered the village, stood us in a row next to the beach, positioned a Bren [a submachine gun] from here and from there, and brought our boats, twelve in number, in order to shoot us. . . Then came three people from Zichron Yaacov who said, "Why are you doing this? Why are you killing [these] people?" They [the soldiers] said to them, "These are Iraqis and Syrians." They [the people from Zichron] said, "These are the people of Tantura, and in the summer we visit them. They give us their houses, and they sleep outside. We spend the summer here. Why are you doing this?" So they made us sit [and stopped the shooting].

[Later in the conversation]

Abu Fibmi: Shimshon Mashvitz gave me two notebooks and two pencils, gave me ten people and two stretchers to pick up the dead from the streets and take them to our graveyard. He told me to write down the names of all of them. He asked me, "Are you a native here?" And I said, "This is my village, and this is my house"-our house was near the harbor.... I wrote down ninety-five men and two women.

[Later in the conversation]

Abu Fihmi: The person who was with me knew Hebrew. He overheard them saying that after they [the diggers] finish the first mass grave, let them dig another one and kill them and put them in it lan action ended by the arrival of people from Zichron Yaacov].

[Later in the conversation]

Katz: You told us that you surrendered. What does it mean?

Abu Fibmi: We raised the white flag.

Katz: Alright, and afterwards they killed, after you raised your hands. How many did they kill?

Abu Fibmi: We have not seen, they collected us together.

Katz: Roughly how many?

Abu Fibmi: According to the announcement made by their army, they said they had killed two hundred and fifty.

Katz: This is all in all. But how many were killed after you raised your hands? Two, four, how many?

Abu Fihmi: This I cannot tell you.

Katz: Roughly?

Abu Fibmi: This I do not know.

Katz: Did you count them? Many or few? 
Abu Fibmi: I am telling you their military announcement said they had killed two hundred and fifty. It is a war military announcement, it was broadcast.

\section{Najiah Abu Amr, from Tantura}

Katz: What do you remember from the day of the occupation?

Abu Amr: They entered the village and killed people. They entered from all directions and killed the guards who watched the village and then collected us and took us from the center of the village toward the east.

Katz: On the beach?

Abu Amr: Yes. First to the beach.

Katz: How long were you there?

Abu Amr: From 0500 to 1400 on the beach.

Katz: All the women?

Abu Amr: All the men and the women, and they were separated. Women on one side, men on the other. And then they took us near the graveyard, brought buses, and took the women and children out of the village.

Katz: What time was this?

Abu Amr: 1500.

Katz: On the way to the graveyard, what did you see?

Abu Amr: Corpses of the dead [begins to list names].

Katz: Did you see men or women?

Abu Amr: I saw one woman killed, and four or five other corpses [gives names].

Katz: But did you see from afar other bodies?

Abu Amr: I have not seen with my own eyes, but I was told there were many dead and that they brought people from Furaydis to bury them [gives names]. But I have not seen them, I was told about them.

Katz: For instance, did you know that the Abu Safiyya family was murdered? How many were they?

Abu Amr: There were [gives ten names of members of the family]. These ten names I remember, but there were thirteen of this family. They were all murdered at the prime of their youth.

Katz: Do you know how many dead were there?

Abu Amr: I know that many people were killed, but I do not know how many. I estimate that there were about 100 dead lagain begins listing names]. There were so many dead in this village, between 100 and $150 \ldots$ Katz: When you reached the graveyard, what did you see?

Abu Amr: I saw the soldiers trying to harass the women, but they were pushed away by the women. And when they saw the women not succumbing, they stopped. When we were on the beach, they took two women and try to undress them, claiming they have to check their bodies. They took a lot of gold from the women. I also saw them tying one young man, Salim Abu Shaqr, and killing him in the house of Ihsan al-'Abd.

Katz: I want to understand this. They took him with his hands tied behind his back? 
Abu Amr: No. They took him from within the groups of the young men, tied him with his jacket, and took him to a faraway house and shot him.

Katz: Why?

Abu Amr: They claimed that he brought weapons into the village. People informed on him. He was very unlucky. His wife, Hayat, is my aunt, a sister of my mother.

\section{Fawzi Mahmoud Tanj (Abu Khalid), from Tantura}

Katz: And what happened on the beach?

Abu Khalid: They took a group of seven to ten young men, each time, took them to the streets and shot them.

Katz: Only the young men?

Abu Khalid: Yes.

Katz: Where did it happen? On the beach?

Abu Khalid: No. They took them to the village.

Katz: They took seven and killed them?

Abu Khalid: Yes. They shot them and came to take another group.

[Later in the conversation]

Katz: How many times they did it?

Abu Khalid: They killed ninety people.

Katz: It means they came and took ten times?

Abu Khalid: Yes.

Katz: How many soldiers came?

Abu Khalid: Many soldiers.

Katz: But with each group?

Abu Khalid: Ten to twelve.

Katz: The same soldiers?

Abu Khalid: No, each group took a group.

Katz: And the village is watching?

Abu Khalid: Yes, and then they took the men away to the graveyard.

Katz: And, tell me, how the people of Zichron stopped it.

Abu Khalid: Wait a minute, I will get there. They brought us to the graveyard.

Katz: That is, those who remained? And you saw . . .

Abu Khalid: We saw the bodies.

Katz: After killing ninety, they took those who remained?

Abu Khalid: Yes, to the graveyard.

Katz: And what happened there?

Abu Khalid: They took us there, seated us, aimed the weapons at us, and wanted to kill us. [Then] the people of Zichron came and said, "These don't [kill]. You have killed enough."

[Later in the conversation]

Katz: Were you present in the digging?

Abu Khalid: Yes.

Katz: The same day? 
Abu Khalid: The same day they took them and dug a big hole.

Katz: How many were killed in the battle itself?

Abu Khalid: Four or five.

\section{Mustafa Masri (Abu Jamil), from Tantura}

Katz: After they occupied the village?

Abu Jamil: An officer took the family-we were fourteen people-and started counting us. [He] says to me, "Come here." "What do you want?" I ask. "You sit with the kids." [Abu Jamil was thirteen at the time.] I said OK. He began questioning each young man: "Were you in the war?" This and that said no. I and the [other] person who was released, we walked twenty meters, and then he kills my father and the whole family.

Katz: This person knew your father from before?

Abu Jamil: No, the person who knew my father handed him to another person. I said to the person we knew, "We know you. We know your wife, your children. You know my father. How could you do this?" He says to me, "In the war, I do not recognize anyone."

Katz: In fact, he saved you and another one?

Abu Jamil: But they killed fourteen members of my family.

Katz: You were the youngest?

Abu Jamil: Yes.

Katz: So it was our luck you were thirteen?

Abu Jamil: No, it was from God. He also killed an old man, I think he was 100. And he killed someone seventeen years old-every man and his fate.

Katz: It means you left, and then heard the shooting?

Abu Jamil: No, we were close. Fifteen meters, no more. I said to him, "Why did you do it?" He said to me, "I was told to kill them. What can you do in a war?"

[Later in the conversation]

Abu Jamil: There was a senior officer from Givat Ada, but not in the army. Katz: You remember his name? I was told something like Shimshon.

Abu Jamil: Yes, Shimshon.

Katz: Shimshon what?

Abu Jamil: I do not remember. After he took them, he shot them directly in the eyes. Then he took two, he had such a whip, and lashed them just for fun....

[Toward the end of the conversation]

Abu Jamil: But believe me, one should not mention these things. I do not want them to take revenge on us, you are going to cause us trouble. I made a mistake in giving you the name of the person who handed my family over. ... 


\section{Notes}

1. Theodore Katz, "The Exodus of the Arabs from Villages at the Foot of Southern Mount Carmel in 1948" (University of Haifa, 1998)

2. Benny Morris, The Birth of the Palestinian Refugee Problem, 1947-1949 (Cambridge: Cambridge University Press, 1988).

3. University of California, Los Angeles, Oral History Program, "Introduction to Oral History," available online at www.library.ucla.edu/libraries/special/ ohp/ohpintro.htm.

4. Yehuda Slutsky, ed., Sefer haHagana, vol. 3, parts 2 and 3 (Tel Aviv: Am Oved, 1972).

5. The Hebrew tiber literally means "to purify."

6. It has recently been learned that a file containing reports on massacres and atrocities in 1948 exists, but it remains sealed. According to Ha'Aretz, Benny Morris appealed to the government to open the files in February 2001, but he was refused.

7. Omer Bartov, "An Infinity of Suffering," Times Literary Supplement, 15 December 2000, p. 6.

8. Walid Khalidi, ed., All That Remains: The Palestinian Villages Occupied and Depopulated by Israel in 1948 (Washington: Institute for Palestine Studies, 1992).

9. Al-Mawsu'a al-Filastiniyya (The Palestine Encyclopedia), 4 vols. (Damascus: Hayat al-Mawsu'a al-Filastiniyya, 1984).

10. A report from Tantura, 23 May 1948, IDF Archives, 922/75.

11. Correspondence from Commander of the Naftali Region (coastal area) in Zichron Yaacov to Alexandroni, 29 May 1948 and 31 May 1948, IDF Archives, 69/ 585.

12. See the internal memo titled "The Robbery of Tantura," 1 June 1948, IDF Archives, 69/374.

13. IDF Files 57/4663/1949, Alexandroni to HQ, 9 June 1948.
14. Nimr al-Khatib, Nakbat Filastin, (Damascus: n.p., n.d.).

15. Mustafa al-Wali, "Majzarat Tantura fi al-Siyaq al-Tarichi li-Tahawid Filastin," Majallat al-Dirasat al-Filastiniyya, no. 43 (Summer 2000), pp. 101-17.

16. Gershon Rivlin and Zvi Sinai, eds., The Alexandroni Brigade in the War of Independence (Tel Aviv: IDF Publications, 1964).

17. At a stormy public meeting about the Tantura case on 15 March 2001 held under the auspices of Tel Aviv University's faculty of law, the lawyer for the defense cited the same six discrepancies he had analyzed at the trial. When asked to provide additional examples, he said he did not have time to go into them; when pressed further, he demurred. During that same meeting, suggestions that permission be sought to excavate the sites of the mass graves at Tantura were shouted down by Alexandroni veterans present.

18. Ha'Aretz, 27 December 2000. No one in the mainstream press defended Katz. My own letters in defense of his work, sent to Ha'Aretz, were never published.

19. Amos Oz expresses this view on behalf of his group in an article published in the Guardian on 13 October 2000.

20. Mordechai Naor, Ha'Aretz, 2 January 2001 .

21. See Walid Khalidi's "Plan Dalet: Master Plan for the Conquest of Palestine," first published in November 1961 in Middle East Forum and reprinted in JPS 28, no. 1 (Autumn 1988), pp. 4-19; and Nur Masalha, Expulsion of the Palestinians: The Concept of "Transfer" in Zionist Political Thought, 1882-1948 (Washington: Institute for Palestine Studies, 1992).

22. See Ilan Pappé, "Were They Expelled? The History, Historiography and Relevance of the Palestinian Refugee Problem" in The Palestinian Exodus, 1948-1998, ed. Ghada Karmi and Eugene Cotran (London: Ithaca Press, 1999), pp. 37-62. 